Lingua 28 (1971) 276-285, (c) North-Holland Publishing Company

Not to be reproduced in any form without written permission frosn the publisher

\title{
THE MEDIEVAL DUTCH FRICATIVES
}

\author{
ROBERT L. KYES
}

The problem with which this paper is concerned is the phonetic nature of the sounds represenied by the graphs $u, f, \int$, and $s$ in the Old Low Franconian (Old Dutch) Psalms and Glosses.

Compared to the written evidence for Old High German, Old Saxon, Old English, and Gothic, the Old Low Franconian corpus is extremely small. We have only a poor sixteenth-century copy of an inaccurate tenth-century translation of twenty-one psalms (the Diez Psalms), an inaccurate printed version of anoth $r$ psalm (Psalm xviii), and a list of some eight hundred OLF words with their Latin equivalents (the Iipsiüs Giosses). ${ }^{1}$ ) Cowan (1959) has shown that the dialect represented in these documents is Limburgic, i.e. Southeast Netherlandic.

Inspection of cognates indicates that the OLF sound or sounds symbrlized by the graphs $u$ an $l f$ reflect the PGmc. voiceless and voiced labial fricatives */f/ and */b/ (see fig. 1). OLF spellings with both $u$ and $f$ occur initially before a vowel, often in variant repre-

\begin{tabular}{l|c|c|c|c|}
\hline $\begin{array}{c}\text { Initially } \\
\text { before } \\
\text { vowel }\end{array}$ & Medially & $\begin{array}{c}\text { Initially } \\
\text { before } \\
\text { consonant }\end{array}$ & Finally \\
\hline PGmc. & $\begin{array}{c}\mathrm{f} / \\
\mathrm{u}, \mathrm{f}\end{array}$ & $/ \mathrm{f} / / \mathrm{b} /$ & $/ \mathrm{f} /$ & $/ \mathrm{f} / / \mathbf{b} /$ \\
$\mathrm{u}$ & $\mathrm{f}$ & $\mathrm{f}$ \\
\hline
\end{tabular}

Fig. 1.

1) The OLF corpus is accessible in the editions of Heyne (1877), Van Helten (1902), Cowan (1957), and Kyes (1969). Cowan's edition does not contain the Glosses. The MS containing the twenty-one OLF Psalms is in the Deutsche Staatsbibliothek in Berlin, and bears the designation Ms Diez C. Quart. 90. The Printed version of Ps. xviii was published by Abraham van der Myle in 1612. The Lipsius Glosses are in the library of the University of Leiden, and are designated Lips. 53.16 fol. 
sentations of the same word, reflecting PGmc. $\left.{ }^{*} / \mathrm{f}^{\prime} /{ }^{2}\right)$ as in uete, feste 'strengih', and uan, fan 'from'. The reflex of PGmc. */f/ alsc appears initialiy before the conson ints $l$ and $r$; here, however, it is spelled only $f$, as in fluode 'river', frithe 'peace' (but never *uluode o" *urithe).

Medially between vowt., and between a liquid and a vowel, the spelling $u$ predominates, suggesting nu-ror of $\mathrm{PGmc} * / \mathbf{f} /$ and $* / \mathbf{b} /$ in a single OLF phoneme. PGmc. $* / \mathrm{i} /$ is reflected in houn 'courts' and in reue 'womb' dat. sg. ; PGmc. */b/appears in genon 'give', liues 'life' gen. sg., seluon 'selves', and in erui 'inheritance'. There are but three instances of spellings other than $u$ for medial reflexes of PGmc. */f/ and $* / b /$; they are habeda 'had' and abivthiu 'thereafter' $(<* / b /)$, and touferes 'magician' gen. sg. $(<* / \mathbf{f} /)$.

In final position the PGmc. labial fricatives are reflected by the OLF graph $f$. We see PGmc. */f/ in hof 'court' and $r e j$ ' womb', and PGmc. */b/ in gaf 'gave' and lif 'life'.

PGmc. */s/ emerges in the OLF corpus in two graphic representations, $\int$ and $s$ (see fig. 2). The latter is the more common of the two,

\begin{tabular}{l|c|c|}
\hline $\begin{array}{c}\text { ?Jon- } \\
\text { inally }\end{array}$ & Finally \\
\hline PGinc. & $/ \mathrm{s} /$ & $\mid \mathrm{s} /$ \\
OLF & $f, \mathrm{~s}$ & $\mathrm{~s}$ \\
\hline
\end{tabular}

Fig. 2.

while $\int$ is restricted to the first half of the Diez MS, where it occurs only in nonfinal position: Jal 'shall', ift 'is', but uuas 'was'. In other words, where the symbol $\int$ occurs, it is in complementary distribution with $s$.

What, if anything, do these orthographic distributions reveal about the phonetic features of the sounds spelled $u, f, \int$, and $s$ in Old Low Franconian? Our answer to this question clearly depends on how we view the relationship between orthography and phonology.

2) The graph $u$ also occurs in variation with $u$, reflecting PGmc. $/ w /$, as in suert 'r word', uuerd 'value'. It may also represent a vowel, as in hulpa 'help', duuon 'doves'. The present discussion is concerned only with those $u$ 's that reflect $\mathrm{PGmc} * / \mathrm{f} /$ or $* / \mathbf{b} /$. 
A typical pre-structuralist view assumed the existence of a one-toone correspondence between graphic symbol and phonetic feature, or between letter and sound, as if medieval scribes practiced a kind of close phonetic transcription. This position is implied in Borgeld's statement: 'De naast de regelmatige schrijfwijze $f$ nu en dan voorkomende spelling $v(u)$ [for the initial prevocalic reflex of $\mathrm{PGmc}$. $* / \mathrm{f} /]$ wijst op stemhebbende labiodentale ui.spraak' (1899: 41). Van Helten was even more precise in his phonetic interpreta'ion: 'Neben normalem, im wortanlaut bez. im anlaut des zweiten compositionsteils stehenden $f$ steht vor vocai ausnahmsweise auch $u$.. Das fehlen von solchem $u$ vor $l$ und $r$ lässt aut einen vor vocal mit geringerer geräuschstärke und schwächerer heramung gesprochenen fricativlaut schliessen' (1902 II: 144). We find the same assumption underlying Cowan's analysis, but he reaches a slightly different conclusion: 'Le phonème /f/, comme le montrert les graphies, avait deux allophones, une sourde et une sonore; c.à-d. qu'il n'y a jamais d'opposition entre [f] et [v] en aucune position, et que, par conséquent, ces variantes n'étaient pas des phonèmes indépendants. Les variantes ne sont pas, cependant, 'libres'; du moins pas dans toutes les positions. En position initiale prévocalique c'est bien le cas, comme le montrent les exemples, uerthe $=$ ferthe $/$ 'ferठə/, uan $=$ fan $/ \mathrm{fan} /$, wilo $=$ filo en filohardo /'filə/, etc.' (1961: 21).

Borgeld and van Helten drew phonetic conclusions from the crthographic data, but without consideration of the phonemic structure. Cowan, while claiming to operate within a structuralist-phonemic framework, assumes a one-to-one relationship between letter and sound (allophone), i.e. $u$ represents [ $\mathrm{v}$ ] in uerthe and $f$ represents [f] in ferthe; he does not regard it as unlikely that scribes should have given graphic shape to sub-phonemic features.

Hoenigswald writes: 'An ideally consistent alphabetic script will employ one grapheme per phoneme; there should be no overlapping between graphs belonging to different phonemes ...' (1960: 5). The attainment of this ideal is not in evidence in any of the extant Germanic documents; indeed, it is but remotely approached in the OLF corpus. To assume such a relationship to exist in the documents under discussion here would soon lead us to reject the notion that hnguistic development is regular, and would open the door to a variety of helter-skelter sound changes. 
It is of little advantage to seei such a relationship between graphemes and systematic phonemes, as has been suggested by Kir.: 'In the absence of strong nonnative orthographic influence, scribes devise symbols for the underlying systematic phonemic segments of the language' (1969: 208-9). Is a matter of unfortunate fact there usually is a strong nonnative influence in the orthographies of medieval Germanic documents; furthermore, such an assumption fails to take into account the enormous amount of orthographic variation that appears in these texts.

For Old Low Franconian we cannot assume a one-to-one correspondence between letters and sounds, or between graphemes and phonemes, or even between written symbols and systematic phonemic segments. The distribution of the graphs $u$ and $f$ allows us to conclude only that they do not correlate with a contrast on the phonemic level. We cannot posit a contrastive relationship between the sounds spelled $u$ and $f$; indeed, on the basis of tite evidence available in the OLF texts themselves, we cannot even assume the existence of more than a single allophone of the phoneme spelled $u$ or $f$. On the other hand, however, the $u \sim t$ spellings do correlate with contrasts represented by other symbols, as is revealed by nearminimal pairs such as fortha 'fear': portun 'gate', fuot 'foot': buoke 'hook', fluode 'river': bluod 'blood', uan fan 'from': man 'man'.

Similarly, ro contrast is revealed by the spellings $\int$ and $s$, yet these contrast with other refresentations: fia $\sim$ sia 'she': thia 'those', uneiscno 'orphans': uieithon 'pasture', fuoia 'sweet': fuot 'foot', unejax: unesan 'be': hewon 'lift', Jie sie 'they': hie 'he'.

As an alternative to the clearly inadequate assumptions discussed above, let us assume simply that a consistently applied graphic distinction implies (but does not necessarily prove) a phonemic contrast among the sounds represented, and that the absence of a consistent graphic distinction implies (but, again, does not necessarily prove) the absence of contrast. On the basis of the distribution of the graphs explained atove, this assumption leads us to posit two fricative phonemes for Old Low Franconian: a single labial fricative, which we may symbolize $/ \mathrm{v} /$, and a single dental fricative, which we may symbolize $/ z /$. The choice of symbols is, of course, arbitrary; we have discovered nothing about the voiced-nese or voiceless-ness of these phonemes, nor are we even justified in calling them labial and 
dentai. For these matters we must examine the evidence offered by later stages of the language.

The situation in New Dutch is relatively complex. To state it briefly: among the inventory of phonemes of New Dutch there are two pairs of contrasting fricatives: voiceless /f/ vs. voiced (or "halfvoiced') $|v|$, and voiceless $\mid s / v s$. voiced $|z|$. The voiced fricatives $/ v \mid$ and $|z|$ do not occur in final position, but all four occur - and thus contrast - initially and medially: fier 'proud': vier 'four', saai 'tedious' : zaai 'sow' imper. (Cohen et al. 1961: 34).

The obstruents of New Dutch are involved in phonologically conditioned morphophonemic alternations extending over morpheme boundaries and word boundaries. The principles, as stated by Shetter (1968: 13), are as follows (I use Shetter's quasi-phonemic spelling):

(1) If a voiced stop comes to stand next to another obstruent, then the resulting sequence will be voiced, as in uit + breiden $\rightarrow$ uidbreiden 'extend', $o p+$ duizenden $\rightarrow o b$ duizenden 'on thousands', $i j s+$ breker $\rightarrow$ ijzbreker 'icebreaker'.

(2) Otherwise the sequence will be voiceless, as in af + zetten $\rightarrow$ afsetten 'take off', het is + veel $\rightarrow$ het is feel 'it is much', op + voureen $\rightarrow$ opfouwen 'fold up'.

The historical conditions for the development of $|v|$ and $|z|$, as opposed to /f/ and /s/, are transparent up to a point. ND /f/ and /v/ reflect a partial coalescence of $P G m c . * / f /$ and $* / b /$ (see fig. 3 ). Initial-

\begin{tabular}{|c|c|c|c|c|}
\hline $\begin{array}{c}\text { Initially } \\
\text { before } \\
\text { vowel }\end{array}$ & Medially & $\begin{array}{c}\text { Initially } \\
\text { before } \\
\text { consonant }\end{array}$ & Finally \\
\hline PGmc. & $/ \mathrm{f} /$ & $\mid \mathrm{f} / / \mathrm{b} /$ & $\mid \mathrm{f} /$ & $\mid \mathrm{f} / / \mathrm{b} /$ \\
$\mathrm{OLF}$ & $/ \mathrm{v} /$ & $/ \mathrm{v} /$ & $/ \mathrm{r} /$ & $/ \mathrm{v} /$ \\
$\mathrm{ND}$ & $(\mathrm{u}, \mathrm{f})$ & $(\mathrm{u})$ & $(\mathrm{f})$ & $(\mathrm{f})$ \\
$\mathrm{N} /$ & $/ \mathrm{v} /$ & $/ \mathrm{v} /$ & $/ \mathrm{f} /$ \\
\hline
\end{tabular}

Fig. 3.

ly, PGmc. */f/ and the OLF fricative spelled $u$ (before vowels) and $f$ (before vowels and consonants) appear in New Dutch as /v/; PGmc. */b/ became a stop in this nosition, so does not enter into the discussion here. Examples of ND initial $/ \mathrm{v} /<\mathrm{OLF} / \mathrm{v} /$ (spelled $u, f$ ) 
$<$ PGmc. */f/are: ND voet 'foot' < OLF fuot; vlocd 'river' < fluode; vrede 'peace' < frithe; veste 'fort' < ueste, feste 'strength'. Medially PGmc. $* / \mathbf{f} /$ and $* / b /$ merged in what is normally spelled $u$ in Old Low Franconian, and are reflected in New Dutch by the phoneme $\mid \mathrm{v} /$ : ND geven 'give' < OLF geuan; halve 'half' < -haluon in osterhaluon 'east side'; hoven 'ge lens' < houon 'courts'. In final position PGmc. */f/ and */b/merged in the OLF sound spelled $f$, and are reflected in New Dutch by /f/: ND gaf 'gave' < OLF gaf; hof 'garden' < hof 'court'.

ND $\mid z /$ and $/ \mathrm{s} /$ reflect $P G m c .{ }^{*} / \mathrm{s} /$, and correspond to what is spelled $f$ or $s$ in Old Low Franconian (see fig. 4). The voiced reflex $|z|$

\begin{tabular}{|c|c|c|c|c|c|}
\hline & $\begin{array}{l}\text { Initially } \\
\text { before } \\
\text { vowel or } \\
\text { semivowel }\end{array}$ & Medially & $\begin{array}{c}\text { Initiaily } \\
\text { before } \\
\text { consonant }\end{array}$ & Finally & Ge rination \\
\hline PGmc. & $|\mathbf{s}|$ & $/ \mathrm{s} !$ & $|s|$ & lof & $\mid \mathrm{ss} /$ \\
\hline OLF & $\begin{array}{c}|z| \\
(f, s)\end{array}$ & $\begin{array}{c}|z| \\
(f, s)\end{array}$ & $\frac{i}{(f, s)}$ & $\begin{array}{l}|z| \\
\text { (s) }\end{array}$ & $\begin{array}{c}l=z^{\prime} \\
\left(\iint, \mathrm{ss}\right)\end{array}$ \\
\hline $\mathrm{ND}$ & $|z|$ & $|z|$ & $|\mathrm{s}|$ & $|s|$ & $|\mathrm{s}|$ \\
\hline
\end{tabular}

Fig. 4.

appears initially before vowels, initially before the sernivowel $/ \mathrm{w} /$, medially between vowels, a.ld medially between a liquid and a vowel: ND zelf 'self' < OLF se'uon; zwaurd 'sword' < $\int i$,ert; duizenid 'thousand' < thusint; onze 'our' < un $a$, unsa. The voiceless refle $\mathrm{x}$ /s/ appears initially before / $\mathrm{m} \mathrm{n} \mathrm{p} \mathrm{t/,} \mathrm{finally,} \mathrm{and} \mathrm{in} \mathrm{gemination:}$ ND slaap 'sleep' < OLF slap; smeer 'grease' < smere; sneeuw 'snow' $<$ snewe; spreken 'speak' < sprecan, sprecon; sterk 'strong' < Jtarca, stark; wes 'was' < unas; gewisse 'indeed' < geunifjo, gemuisso.

In apparent contradiction to the above patterns of distribution, however, some ND words have voiceless /f $/$ and /s/ initially or medially, where we would expect voiced $/ v /$ and $/ z /$. These words can be divided into three groups:

(1) Those whose initial voiced fricative had been devoiced through assimilation to a preceding stop which has since been lost, such as samen 'together' < *tsamen < *tezamen, and sestig 'sixty' < 'tsestig $<{ }^{*}$ ant-sexs-tij (cf. OS ant-ahtoda 'eighty'); see Franck (1910: 194) and Schönfeld (1959:5\%) for details and additional examples. 
(2) Those of foreign origin, e.g. sint 'saint' from French saint, feit 'fact' from Fr. feit, etc.

(3) Those whose initial voiceless fricatives have not been satisfactorily explained. Schönfeld (1959: 57) suggests the possibility of 'psychic intensity' to account for some of these, e.g. the /f/ in flawe 'weak' and flets 'pallid', and the is/ in sijpelen 'ooze'.

Were it not for these three sets of words, the ND voiceless and voiced fricatives that reflect $P G m c$. $* / f /$ and $* / b /$, and those that reflect $\mathrm{PGmc}$. */s/, would be in perfect complementary distribution. The Sandhi variations among the obstruents of New Dutch would then simply be instances of conditioned allophonic alternation.

As early as the twelfth century there emerged a tendency to standardize the spellings of tnese fricatives. The tendency was to spell the initial reflex of PGmc. */f/, and the medial reflex of PGmc. */f/ and $* \mid b /$ - that is, those fricatives that are represented in Old Low Franconian by the graphs $u$ and $f$ - with the symbol $v$, and to spell their final reflex with $f$; Middle Dutch has the forms veste 'strength', vrede 'peace', vleesch 'flesh', grave 'grave', sterven 'die', but lijf 'life', erf 'inheritance'. In Middle Dutch the symbol $f$ was employed in initial position only to render certain loan words, most of which were coming into Dutch from French (Kern 1891: 64, and Van Loey 1949: 85), such as faute 'fault', familie 'family', feeste 'feast', flute 'flu te', fraude 'fraud', fonteine 'fountain'. In medial position $p h$ often occurs, as in prophete 'prophet'.

The MD reflexes of $\mathrm{PGmc} .{ }^{*} / \mathrm{s} /$ reveal a similar development. Spellings with $z$ initially and medially are rare in early Middle Dutch, but become increasingly frequent in the thirteenth century (Franck 1910: 75; Kern 1891: 78; Van Loey 1948: 97; and Schönfeld 1959: 78). As these $z$-spellings became more and more frequent, however, loan words from French with initial [s] came to be rendered with $s$ or $c$, as in ceder 'cedar', citeit 'city', saerge 'serge', sacrament 'sacrament', saint 'saint', sikkele 'sickle'.

It appears, then, that there was a growing tendency in Middle Dutch to employ the graph $f$ to contrast with $j$, and to use $s$ and $c$ in contrast to $z$. If we are correct in assuming that a consistently applied graphic distinction implies a phonemic distinction, then we may conclude that this orthographic development, too, was correlated with the development of a phonemic contrast. This phonemic contrast, in turn, implies something about the phonetic nature of 
the sounds prior to the introduction of the French loans with initial and medial [f] and [s]. The new contrast between voiced $/ \mathrm{v} z /$ and voiceless /f $\mathrm{s} /$ was preceded by a stage in which there were only two phonemes - we have called them $\mid \mathrm{v} /$ and $|z|$ - each of which had a voiced allophone and a voicrless allophone (see figs. 5 and 6 ).

\begin{tabular}{|c|c|c|c|c|}
\hline & $\begin{array}{c}\text { Initially } \\
\text { before } \\
\text { vowel }\end{array}$ & Medially & $\begin{array}{l}\text { Initially } \\
\text { before } \\
\text { consonant }\end{array}$ & Finally \\
\hline PGmc. & $/ \mathrm{f} /$ & $|f||b|$ & /f & $|\mathfrak{f}||\mathfrak{b}|$ \\
\hline OLF & $\begin{array}{c}|v|=[v] \\
(u, f)\end{array}$ & $\underset{(\mathrm{u})}{|\mathrm{v}|=[\mathrm{v}]}$ & $\mid \mathrm{v} / \underset{(\mathrm{f})}{=}[\mathrm{v}]$ & $\mid \mathrm{v} /=[\mathrm{f}]$ \\
\hline ID:Fr. & $\begin{array}{l}/ v /: / f / \\
(v)(f)\end{array}$ & $\begin{array}{c}/ v /: / f / \\
\text { (v) (f, ph) }\end{array}$ & $\begin{array}{l}/ \mathrm{v} /: / \mathrm{f} / \\
(\mathrm{v})(\mathrm{f})\end{array}$ & $\begin{array}{l}/ f / \\
\text { (f) }\end{array}$ \\
\hline
\end{tabular}

Fig. 5.

\begin{tabular}{|c|c|c|c|c|c|}
\hline & $\begin{array}{l}\text { Initially } \\
\text { before } \\
\text { vowel or } \\
\text { semivowel }\end{array}$ & Medially & $\begin{array}{l}\text { Initially } \\
\text { before } \\
\text { consonant }\end{array}$ & Finally & Geminatiun \\
\hline PGmc. & $|s|$ & $|s|$ & $|s|$ & $|s|$ & $/ \mathrm{ss} /$ \\
\hline OLF & $\begin{array}{c}|z|=[z] \\
(\delta, s)\end{array}$ & $\begin{array}{c}|z|=[z] \\
\left(\int, \mathrm{s}\right)\end{array}$ & $\begin{array}{c}|z|=[\mathrm{s}] \\
(\delta, \mathrm{s})\end{array}$ & $\underset{(\mathrm{s})}{|\mathrm{z}|=[\mathrm{s}]}$ & $\begin{array}{c}|\mathrm{zz}|==[\mathrm{ss}] \\
\left(\iint, \mathrm{ss}\right)\end{array}$ \\
\hline MD:Fr. & $\begin{array}{c}|z|: / s \mid \\
(z)(s, c j\end{array}$ & $\begin{array}{c}|z|: / s \mid \\
(z)(s, c)\end{array}$ & $\begin{array}{l}|\mathrm{s}| \\
(\mathrm{s})\end{array}$ & $\begin{array}{l}|s| \\
\text { (s) }\end{array}$ & $\begin{array}{l}\text { /ss/ } \\
\text { (ss) }\end{array}$ \\
\hline
\end{tabular}

Fig. 6.

For OLF /v/, the voiced allophone [v] nccurred initially before vowels, initially before $l$ and $r$, medialiy between vowels, and between a liquid and a vowe.. The voiccless allophone [f] occurred finally. There are no examples of an OLF reflex of PGmc. geminate */ff/.

For OLF $/ z /$, the voiced allophone [z] occurred initially before vowels, initially before $/ w /$, medially between vowels, and between a liquid or nasal and a vowel. The voiceless allophone occurred finally, initially before consonants, and in gemination.

Phonemicization of these allophones was precipitated by the introduction of French loan words containing voiceless fricatives in po- 
sitions where only voiced fricatives occurred in native Dutch words. This, then, is an instance of phonemic split through borrowing. What was borrowed was not a new set of phonemes, however, but rather a pattern of distribution that differed from the native Dutch pattern.

The phonetic nature of the sounds spolled $u, f, \therefore$ and $s$ in Old Franconian may be a matter of relatively minor impe rtance. The problem serves as an illustration of how the representations of later stages of a language may cast some light upon earlier stages, particularly when the most direct evidence for those eariier stages - the written documents - is so small, so ambiguous, or so erroneous as to permit only a very tentative analysis.

Dept. of Germanic Languages

and Literatures, Univ. of Michigan, Arn Arbor, Mich. 48ro4, U.S.A.

\section{REFERENCES}

Borgerd, Andries, 1899. De Oudoostnederfrankische psalmen: Klank-en vormleer. Groningen, Wolters.

Cohen, A., C. L. Ebeling, K. Fokkema and A. G. F. van Holk, 1961. Fonologie van het Nederlands en het Fries, 2nd ed. 's-Gravenhage, Nijhoff.

Cowas, H. K. J., Ed., 1957. De Oudnederlandse (Oudnederfrankische) psalmenfragmenten. Textus minores, vol. 23. Leiden, Brill.

CowAN, H. K. J., 1959. 'De localisering van het Oudnederfrankisch der psalmenfragmenten', Lewvense Bijdragen 48, $1-47$.

CowAN, H. K. J., 1961. 'Esquisse d'une grammaire fonctionnelle du vieuxnéerlandais (vieux bas-francique) (d'après le psautier carolingien de Wachtendonck)', Leuvense Bijdragen 50, 2-58.

Frawck, Johannes, 1910. Mittelniederländische Grammatik, 2nd ed. Leipzig, Tauchnitz.

Heyne, Moritz, (ed.), 1877. Kleinere altniederdeutsche Denkmäler, 2nd ed. Paderborn, Schöningh.

HozNigswald, Henry M., 1960. Language change and linguistic reconstructicn. Chicago, University oi Chicago Press.

KERN, Johan Hendrik, 1891. Klankleer der Limburgsche sermoenen. Groningen, Wolters.

KING, Robert D., 1969. Historical linguistics and generative grammav. Englewood Cliffs, Prentice-Hall. 
Kyes, Robert L., Ed., 1969. The Old Low Franconian psalms and glosses. Ann Arbor, University of Michigan Press.

SchöNFEID, M. Schönteld's historische grammatica van het Nederlands, Ed. Adolphe van Loey, 6th ed. Zutphen, Thieme.

Van Helten, Willem Lodewijk, 1902. Die altostniederfrankischen Psalmenfragmente, die Lipsius'schen Glossen und die altsüdmitteltränkischen Psalmentragmente. 2 vols, Groningen, Wolters.

VAN LOEY, Adolphe, 1949. Middelnederlandse spraakkunst, Vol. 2, Klankleer. Groningen, Wolters.

VAN DER MYle, Abraham, 1612. Lingua Belgica. Lugduni Batavorum. 